\title{
Nelly DaszKiewicz
}

Politechnika Gdańska, Polska • Gdansk University of Technology, Poland

\section{Terytorialny zakres internacjonalizacii polskich przedsiębiorstw: wyniki ankietyzacii'}

\section{Territorial Range of Internationalization of Polish Enterprises: Questionnaire Results}

Streszczenie: W liczącej już kilka dekad literaturze dotyczącej internacjonalizacji przedsiębiorstw istnieje wiele nurtów badawczych, których systematyki dokonywano wielokrotnie. Terytorialny zakres internacjonalizacji należy do najstarszych problemów badawczych w dziedzinie procesu internacjonalizacji przedsiębiorstwa. Początkowo był on analizowany jako koncentracja vs. dywersyfikacja (Ayal, Zif, 1978). Obecnie zakres internacjonalizacji jest jednym ze składników większości mierników jej stopnia (Kuivalainen, Sundqvist, Saarenko, 2012). Na ogół małe i średnie przedsiębiorstwa w początkowych etapach procesu internacjonalizacji dokonują ekspansji na bliskie lub sąsiadujące rynki, na których tzw. dystans psychiczny (psychic distance) jest mały (Johanson, Vahlne, 1977). Natomiast przedsiębiorstwa transnarodowe, multinarodowe i globalne częściej funkcjonują na rynkach globalnych (Vahlne, Ivarssonn, 2014; Wach, 2014). Ponadto na zakres internacjonalizacji wpływają też inne czynniki, np. branża, w której działa firma, innowacyjność czy zaawansowanie technologiczne (high-tech/ low-tech) (Daszkiewicz, 2015). Głównymi celami empirycznymi artykułu są: identyfikacja kluczowych czynników determinujących terytorialny zakres internacjonalizacji badanych przedsiębiorstw oraz określenie siły wpływu tych czynników na zakres ich działalności międzynarodowej. Artykuł prezentuje cząstkowe wyniki badań przeprowadzonych na próbie 355 zinternacjonalizowanych przedsiębiorstw. Przebadano je za pomocą kwestionariusza ankiety przy wykorzystaniu wywiadów CATI (Computer Assisted Telephone Interviewing). Ankietyzacja została przeprowadzona w 2015 roku w ramach grantu OPUS realizowanego na Wydziale Ekonomii i Stosunków Międzynarodowych Uniwersytetu Ekonomicznego w Krakowie. Obliczenia zostały wykonane za pomocą programu Statistica ${ }^{\circledR}$ PL v. 10.

Abstract: For several decades in dynamically growing internationalization literature there have been many research trends. The territorial scope of internationalization is one of the oldest research problems in the area of the internationalization process of the enterprise. It was originally analyzed as concentration vs. diversification (Ayal, Ziph, 1978). Currently, the scope of internationalization is one

${ }^{1}$ Artykuł powstał w ramach projektu badawczego pt. Zachowania polskich przedsiębiorstw w procesie internacjonalizacji w świetle szkoły przedsiębiorczości międzynarodowej (OPUS 4) realizowanego w latach 2013-2016 na Wydziale Ekonomii i Stosunków Międzynarodowych Uniwersytetu Ekonomicznego w Krakowie. Projekt został sfinansowany ze środków Narodowego Centrum Nauki przyznanych na podstawie decyzji numer DEC-2012/07/B/HS4/00701. 
of the components of most measures of the extent of internationalization (Kuivalainen, Sundqvist, Saarenko, 2012). In general, small and medium-sized enterprises in the early stages of the process of internationalization carry out expansion in the close/neighboring markets where the so-called psychic distance is small (Johanson, Vahlne, 1977). Conversely, transnational, multinational and global firms frequently operate in global markets (Vahlne, Ivarssonn, 2014; Wach, 2014). In addition, the scope of internationalization is also affected by other factors, e.g. industry in which the firm operates, innovation and technological sophistication (high-tech / low-tech) (Daszkiewicz, 2015). The main empirical objective of the article is to identify the key determinants of the territorial scope of internationalization of the surveyed enterprises, and the impact of these factors on the scope of their international activities. The article presents partial results of research carried out on a sample of 355 internationalized enterprises. Firms were interviewed by questionnaire using CATI interviews (Computer Assisted Telephone Interviewing). The questionnaire was carried out in 2015 under a grant OPUS carried out at the Department of Economics and International Relations, University of Economics in Kraków. CalculationsweremadeusingStatistica ${ }^{\circledR}$ PL v. 10.

Słowa kluczowe: dystans; dystans psychiczny; internacjonalizacja; zakres terytorialny

Keywords: distance; internationalization; psychic distance; territorial scope

Otrzymano: 29 grudnia 2015

Received: 29 December 2015

Zaakceptowano: 28 marca 2016

Accepted: 28 March 2016

\section{Sugerowana cytacja / Suggested citation:}

Daszkiewicz, N. (2016). Terytorialny zakres internacjonalizacji polskich przedsiębiorstw: wyniki ankietyzacji. Prace Komisji Geografii Przemystu Polskiego Towarzystwa Geograficznego, 30(1), 21-29.

\section{DYSTANS W PROCESIE INTERNACJONALIZACJI PRZEDSIĘBIORSTW}

Znaczenie dystansu w biznesie międzynarodowym (BM) ma charakter wielowymiarowy i odnosi się do różnic między krajami czy narodami, których zakres może dotyczyć wielu obszarów (Ciszewska-Minaric, Wąsowska, 2012). Za pierwszą wielowymiarową typologię dystansu uznawany jest powszechnie model CAGE (ang. cultural, administrative, georaphical, economic) opracowany przez P. Ghemawata w 2001 roku. Autor ten zauważył, że przedsiębiorstwa często przeceniają atrakcyjność rynków zagranicznych, nie doceniają natomiast trudności związanych z wejściem na nowe, często bardzo zróżnicowane terytoria (Ghemawat, 2001). Problem ten tkwi w znacznej mierze w narzędziach analitycznych (np. analizie portfolio), które menedżerowie wykorzystują do oceny inwestycji międzynarodowych. Przedsiębiorstwa skupiają się na bogactwie narodowym, dochodach konsumentów i skłonności ludzi do konsumpcji, nie doceniając przy tym kosztów i ryzyka wynikającego $\mathrm{z}$ barier tworzonych przez dystans.

Jednak w modelu CAGE dystans jest rozumiany znacznie szerzej niż tylko w znaczeniu geograficznym. Również inne wymiary dystansu mogą uczynić rynki zagraniczne bardziej lub mniej atrakcyjnymi dla przedsiębiorstwa. I tak w ramach modelu CAGE uwzględniono cztery wymiary dystansu: 
1) kulturowy (cultural distance) - obejmujący wierzenia religijne, rasę, normy społeczne i język odmienne dla kraju docelowego i kraju przedsiębiorstwa rozważającego ekspansję,

2) administracyjny (lub polityczny) (administrative distance) - odnoszący się do powiązań kolonia-kolonizator, wspólnej waluty czy porozumień handlowych,

3) dystans geograficzny (geographic distance) - obejmujący fizyczną odległość między krajami, wielkość kraju docelowego, dostęp do dróg wodnych i oceanu, wewnętrzną topografię, komunikację i transport oraz infrastrukturę,

4) dystans ekonomiczny (economic distance) - dotyczący różnic w bogactwie krajów lub dochodach ludności czy różnic w kosztach bądź jakości zasobów.

Wykorzystując model CAGE, Ghemawat wyjaśnia, w jaki sposób potencjalne rynki mogą być oddalone od istniejących oraz jak różne rodzaje dystansu mogą wpływać na różne branże. Pokazuje też, jak bardzo uwzględnienie dystansu może wpłynąć na obraz danej firmy i wybór jej strategicznych opcji.

Z kolei pojęcie dystansu psychicznego (psychic distance) jest ściśle związane z etapową teorią internacjonalizacji przedsiębiorstw i stanowi fundament modelu uppsalskiego (U-Model), który uważa się powszechnie za pionierski, najbardziej znany i najczęściej cytowany. Model ten został opracowany przez szwedzkich badaczy J. Johansona i J.E. Vahlne'a (1977) przy współudziale F. Wiedersheima-Paula (Johanson, Wiedersheim-Paul, 1975; Daszkiewicz, 2014). U-model powstał w wyniku obserwacji zachowań szwedzkich przedsiębiorstw na rynkach międzynarodowych w połowie lat siedemdziesiątych XX wieku. Firmy te często rozpoczynały internacjonalizację od eksportu ad hoc, a następnie rozwijały swoją działalność małymi kroczkami (in small steps). Proces internacjonalizacji jest w tym modelu rozumiany jako „oddziaływanie między rozwojem wiedzy o obcych rynkach i działań z jednej strony, a rosnącym zaangażowaniem zasobów na rynkach z drugiej strony" (Johanson, Vahlne, 1990: 11-24). Trzeba jednak podkreślić, że podstawą U-modelu jest teoria behawioralna oraz teoria oparta na zasobach. Przedsiębiorstwa przeważnie rozpoczynają internacjonalizację w krajach dobrze im znanych, najczęściej sąsiednich. Następnie poszukują nowych możliwości na mniej znanych rynkach, od których dzieli je większy dystans psychiczny, który jest tu rozumiany jako postrzegane koszty uczenia się lub redukcji niepewności związanej z działaniem w warunkach ,różnic dotyczących języka, systemów edukacji, praktyk biznesowych, kultury oraz poziomu rozwoju przemysłu" (Johanson, Vahlne, 1977: 24).

Z kolei K. Nordstrom i J.E. Vahlne (1994) definiują dystans psychiczny jako zbiór czynników powstrzymujących lub utrudniających firmie proces uczenia się oraz rozumienia specyfiki otoczenia zagranicznego, a S. O'Grady i H.W. Lane (1996) jako poziom postrzeganej niepewności związanej z funkcjonowaniem na rynkach zagranicznych, wynikającej z różnic kulturowych oraz innych czynników utrudniających uczenie się i działanie na danym rynku.

M. Ciszewska-Minaric i A. Wąsowska (2012) zwracają uwagę, że dystans psychiczny nie jest tożsamy z dystansem kulturowym, mimo że w pracach empirycznych pojęcia te używane są czasami wymiennie i mierzone są w taki sam sposób. Dystans psychiczny jest wypadkową czterech pozostałych dystansów uwzględnionych w modelu CAGE. Jednak dystans psychiczny, w przeciwieństwie do kulturowego, dotyczy różnic między krajami postrzeganych przez 
menedżerów, natomiast dystans psychiczny odnosi się do percepcji, tj. zjawisk zachodzących w umyśle jednostki. Dlatego też, konkludują autorki, dystans psychiczny nie powinien być operacjonalizowany za pomocą wskaźników „obiektywnych” (poziom edukacji, język czy poziom PKB per capita). Ponadto według szkoły uppsalskiej dystans psychiczny dotyczy wielu wymiarów różnic między krajami, takich jak język, kultura, system polityczny, poziom edukacji oraz stopień rozwoju przemysłowego (Johanson, Wiedersheim-Paul, 1975).

Należy jednak zaznaczyć, że U-model był aż czterokrotnie modyfikowany w odpowiedzi na zmiany zachodzące $\mathrm{w}$ światowej gospodarce (m.in. postępujące procesy integracji i globalizacji, powstanie jednolitego rynku europejskiego). Już na początku lat osiemdziesiątych XX wieku zauważono przedsiębiorstwa przeskakujące (leapfrogg) niektóre etapy (Cannon, Willis, 1981). Co więcej, rozpoczynały i rozwijały one działalność międzynarodową od początku lub wkrótce po powstaniu. Obecnie firmy te zalicza się do grupy tzw. wcześnie i szybko umiędzynarodowionych. W literaturze przedmiotu znajdziemy wiele terminów dla tej grupy, jak born globals (BGs), international new ventures (INVs), born internationals, innate exporters czy global start-ups. Wczesna i szybka internacjonalizacja początkowo dotyczyła głównie firm funkcjonujących w branżach high-tech i powiązanych z high-tech. Stąd też można znaleźć w literaturze przedmiotu również takie określenia, jak: high technology start-ups, new technology-based / technology-based firms, high-tech new ventures (Duliniec, 2011: 67-68; Jarosiński, 2013: 186-193; Daszkiewicz, 2014).

Na podstawie wyników badań przeprowadzonych na grupie przedsiębiorstw z branży software J. Bell (1995) wykazał, że ok. 30-50\% firm rozpoczynających eksport do krajów, których nie można określić jako psychologicznie czy geograficznie bliskie, internacjonalizuje się szybko i nie podąża ścieżką etapową. Wniosek ten wywołał trwającą do dzisiaj dyskusję o roli dystansu psychicznego i geograficznego w procesie internacjonalizacji przedsiębiorstw funkcjonujących w sektorach opartych na wiedzy (knowledge-intensive) (Madsen, Servais, 1997).

A. Ojala i T. Kontinen (2010), którzy przeanalizowali wyniki badań dotyczących dystansu $\mathrm{w}$ procesie internacjonalizacji małych i średnich przedsiębiorstw funkcjonujących w branży software, doszli do wniosku, że proces internacjonalizacji firm software oraz firm średnich jest w znacznym stopniu niezależny od efektu psychicznego i geograficznego dystansu. Dlatego też sami przeprowadzili badania dotyczące wzorców wejścia tej grupy przedsiębiorstw na rynki zagraniczne. Uzyskane wyniki prowadzą do wniosku, że najczęściej firmy te nie podążają etapową ścieżką (step-wise) od rynków bliskich do bardziej odległych. Naukowcy zwrócili natomiast uwagę na niebadany dotychczas problem, tj. jaki jest efekt dystansu psychicznego i geograficznego, kiedy przedsiębiorstwa wchodzą na odległe rynki zagraniczne. W tym przypadku wyniki badań pokazały, że dystans psychiczny i geograficzny hamują wejście firm na rynki zagraniczne. Z drugiej strony, wejście to było ułatwiane przez czynniki skracające dystans, które badacze określili jako:

1) budowanie pomostu nad dystansem (distance-bridging), np. rekrutacja zdolnych pracowników, wybór odpowiednich form wejścia, sieci, wcześniejsze doświadczenie,

2) kondensowanie dystansu (distance-compressing) - odnoszące się do zmian makroekonomicznych, jak: ruchy społeczne, zmiany instytucjonalne, globalizacja i rozwój technologiczny. 
Vahlne i I. Ivarsson (2014) próbowali zrozumieć, dlaczego niektóre firmy osiągają status globalnych. W celu wyjaśnienia procesu globalizacji szwedzkich firm multinarodowych zaproponowali model procesu globalizacji (globalization process model), który jest rozwinięciem i adaptacją U-modelu (Johanson, Vahlne, 1977). Model objaśnia, jakie zdolności pomagają przedsiębiorstwom wzmacniać specyficzną przewagę firmy i uczą radzenia sobie z różnicami instytucjonalnymi między krajami i regionami.

\section{DOBÓR I CHARAKTERYSTYKA PRÓBY BADAWCZEJ}

Warstwowo-losowy dobór przedsiębiorstw do próby badawczej został sporządzony na podstawie bazy REGON. Spośród 7100 firm ostatecznie w badaniu wzięło udział 355 (5\%). W badaniu uwzględniono tylko firmy zinternacjonalizowane (co najmniej eksporterzy) ${ }^{2}$ oraz wszystkie grupy wielkości przedsiębiorstw. Założono, że udział małych i średnich przedsiębiorstw w końcowej próbie powinien stanowić 25-45\%, natomiast udział mikroprzedsiębiorstw (jako najmniej zinternacjonalizowanych) i dużych przedsiębiorstw (są najmniejszą grupą w populacji) łącznie $10-15 \%$ (tab. 1).

Tab. 1. Charakterystyka próby badawczej

\begin{tabular}{|l|c|}
\hline \multicolumn{1}{|c|}{ Wielkość firm } & Udział w próbie (\%) \\
\hline mikro & 14,1 \\
\hline małe & 43,1 \\
\hline średnie & 29,8 \\
\hline duże & 13,0 \\
\hline
\end{tabular}

Źródło: opracowanie własne na podstawie wyników badań $(n=355)$

Wśród badanych przedsiębiorstw aż 75,2\% było aktywnych tylko na rynkach krajów należących do Unii Europejskiej (UE), a 22,8\% oprócz krajów UE działało też na rynkach krajów spoza UE. Tylko 2\% przedsiębiorstw prowadziło działalność wyłącznie na rynkach krajów nienależących do UE (tab. 2).

Tab. 2. Zakres terytorialny badanych firm

\begin{tabular}{|l|c|c|}
\hline \multicolumn{1}{|c|}{ Zakres terytorialny } & Liczba & Udział (\%) \\
\hline rynki krajów należących do UE & 267 & 75,2 \\
\hline $\begin{array}{l}\text { rynki krajów należących do UE oraz rynki } \\
\text { krajów spoza UE }\end{array}$ & 81 & 22,8 \\
\hline tylko rynki krajów spoza UE & 7 & 2,0 \\
\hline suma & 355 & 100,0 \\
\hline
\end{tabular}

Źródło: opracowanie własne na podstawie wyników badań $(n=355)$

${ }^{2} \mathrm{~W}$ literaturze przedmiotu oraz licznych badaniach za przedsiębiorstwa umiędzynarodowione uznaje się również importerów. Przy obecnym poziomie rozwoju powiązań międzynarodowych, przyjmując import jako kryterium umiędzynarodowienia, niemal każde przedsiębiorstwo można by uznać za zinternacjonalizowane (różniły by się w zasadzie tylko stopniem internacjonalizacji). Dlatego też w badaniu za kryterium umiędzynarodowienia przyjęto eksport. 
W badanej próbie przedsiębiorstw aż 58,6\%, zgodnie z przyjętą klasyfikacją, można zaliczyć do grupy born global, tzn. firm, które podjęły pierwsze działania na rynkach zagranicznych w czasie krótszym niż trzy lata od powstania. W przypadku 38,4\% badanych przedsiębiorstw pierwsza ekspansja nastąpiła po czasie dłuższym niż trzy lata od założenia firmy. Pozostałe 3\% przedsiębiorstw nie udzieliło odpowiedzi (tab. 3).

Tab. 3. Szybkość internacjonalizacji

\begin{tabular}{|l|c|c|}
\hline \multicolumn{1}{|c|}{ Szybkość } & Liczba & Udział (\%) \\
\hline$<=3$ lata & 208 & 58,6 \\
\hline$<3$ lata & 136 & 38,4 \\
\hline braki & 11 & 3,0 \\
\hline
\end{tabular}

Źródło: opracowanie własne na podstawie wyników badań $(n=355)$

Przedsiębiorstwa przebadano za pomocą kwestionariusza ankiety przy użyciu tzw. wywiadów CATI (ang. Computer Assisted Telephone Interviewing).

Obliczenia uzyskanych wyników badania zostały wykonane za pomocą programu Statistica ${ }^{\circledR}$ PL v. 10. Poziom statystycznej istotności (alpha lub $\alpha$ ) do testowania hipotez został ustalony na poziomie $\alpha=0,05$, a jako poziom dopuszczalny nieodrzucenia hipotezy zerowej przyjęto poziom $\mathrm{p}<0,1$.

Do weryfikacji postawionych hipotez badawczych wykorzystano następujące mierniki statystyczne: $\chi^{2}$ Pearsona oraz współczynnik kontyngencji V Cramera, co wynika z rodzaju analizowanych danych, które narzuciły konieczność stosowania statystyk nieparametrycznych.

$\mathrm{Na}$ podstawie analizy literatury przedmiotu sformułowano następujące hipotezy badawcze:

H1: Przedsiębiorstwa born globals funkcjonują na większej liczbie rynków niż firmy, które podjęły pierwsze działania na rynkach zagranicznych później niż trzy lata od powstania.

H2: Przedsiębiorstwa działające w branżach bardziej wrażliwych na internacjonalizację (np. w branżach globalnych, których charakter wymusza intensywną działalność międzynarodową) mają większy zasięg terytorialny od firm działających w branżach mniej wrażliwych na internacjonalizację (np. w branżach związanych lokalizacją lokalną lub regionalną).

H3: Przedsiębiorstwa, które mają zaplanowaną strategię internacjonalizacji, działają na większej liczbie rynków niż firmy, które nie opracowały tej strategii.

H4: Wraz ze wzrostem udziału sprzedaży zagranicznej w całkowitej sprzedaży przedsiębiorstwa rośnie jego zasięg internacjonalizacji.

\section{STATYSTYCZNA ANALIZA WYNIKÓW BADAŃ EMPIRYCZNYCH}

1) Istnieje statystycznie istotna zależność pomiędzy tempem internacjonalizacji a liczbą rynków, na których firma funkcjonuje $\left(\chi^{2}=52,75339, \mathrm{df}=33, \mathrm{p}=0,01595\right.$, współczynnik kontyngencji V Cramera $=0,3916030)$. Jest to zależność o umiarkowanej sile. 
2) Istnieje statystycznie istotna zależność pomiędzy wrażliwością branży na internacjonalizację a jej zasięgiem terytorialnym $\left(\chi^{2}=70,36983, \mathrm{df}=6, \mathrm{p}=0,000\right.$, współczynnik kontyngencji V Cramera $=0,3148213)$. Jest to zależność o umiarkowanej sile.

3) Istnieje statystycznie istotna zależność pomiędzy posiadaniem przez firmę zaplanowanej strategii internacjonalizacji a jej zasięgiem terytorialnym $\left(\chi^{2}=8,250503\right.$, df $=4$, $\mathrm{p}=0,08282$, współczynnik kontyngencji V Cramera $=0,1007798)$. Jest to zależność o słabej sile.

4) Istnieje statystycznie istotna zależność pomiędzy udziałem sprzedaży zagranicznej w sprzedaży całkowitej a jej zasięgiem terytorialnym $\left(\chi^{2}=99,97053, \mathrm{df}=78, \mathrm{p}=0,04757\right.$, współczynnik kontyngencji V Cramera $=0,28355)$. Jest to zależność o umiarkowanej sile.

\section{WNIOSKI}

W toku kalkulacji statystycznych wykazano, że:

1) Przedsiębiorstwa born globals funkcjonują na większej liczbie rynków niż firmy, które podjęły pierwsze działania na rynkach zagranicznych w czasie dłuższym niż trzy lata od powstania.

2) Przedsiębiorstwa działające w branżach wrażliwych na internacjonalizację mają większy zasięg terytorialny od firm działających w branżach mniej wrażliwych.

3) Przedsiębiorstwa, które mają zaplanowaną strategię internacjonalizacji, działają na większej liczbie rynków niż przedsiębiorstwa, które takiej strategii nie posiadają.

4) Wraz ze wzrostem udziału sprzedaży zagranicznej w całkowitej sprzedaży przedsiębiorstwa rośnie jego zasięg internacjonalizacji.

\section{Podsumowanie}

Z uwagi na dynamiczny rozwój technologii komunikacyjnych oraz postępujące procesy globalizacji i integracji gospodarek wielu autorów uważa, że dystans traci znaczenie w procesie internacjonalizacji przedsiębiorstwa. Jednak wyniki badań prowadzonych na świecie są wysoce niejednoznaczne, a pytanie o znaczenie dystansu nadal pozostaje aktualne.

Przedstawiony fragment badań stanowi jedynie mały przyczynek do ogromnego dorobku w analizowanym obszarze. Trzeba jednak wziąć pod uwagę, że polskie firmy dołączyły do jednolitego rynku europejskiego dopiero przed dekadą, co może oznaczać, że dystans ma dla nich większe znaczenie niż dla przedsiębiorstw, które powstały i rozwijały się w bardziej dojrzałych gospodarkach rynkowych.

W świetle wyników licznych badań twierdzenie, że dystans traci znaczenie w procesie internacjonalizacji, jest przedwczesne, zwłaszcza dla gospodarek transformowanych. Również wyniki przedstawionych badań wskazują, że dystans ma znaczenie w procesie internacjonalizacji firm. Co więcej, problem dystansu w procesie umiędzynarodowienia przedsiębiorstw stwarza nowe możliwości badawcze. Kierunki dalszych badań mogą dotyczyć różnych wymiarów dystansu oraz powiązań między nimi, znaczenia dystansu w przypadku firm born globals, high-techs i działających w sektorach opartych na wiedzy oraz znaczenia dystansu (jego różnych wymiarów) na rynkach bardziej odległych. 


\section{Literatura \\ References}

Ayal, I., Zif, J. (1978). Competitive Market Choice Strategies in Multinational Marketing. Columbia Journal of World Business, 13(3).

Bell, J. (1995). The Internationalization of Small Computer Software Firms: A Further Challenge to "Stage" Theories. European Journal of Marketing, 29(8), 60-75.

Cannon, T., Willis, M. (1981). The Smaller Firm in International Trade. European Small Business Journal, 1(3).

Ciszewska-Minaric, M., Wąsowska, A. (2012). Znaczenie dystansu w procesie internacjonalizacji przedsiębiorstw. Management and Business Administration. Central Europe, 6(119), 3-22.

Daszkiewicz, N. (2014). Firm-Level Internationalisation from the Theoretical Perspective: Knowledgebased Approach. W: N. Daszkiewicz, K. Wach (red.). Firm-Level Internationalisation and Its Businass Environment. Gdańsk: Gddańsk University of Technology Publishing House, 9-18.

Daszkiewicz, N. (2015). Internationalisation of Born Globals from The Theoretical Perspective. Problemy Zarzadzania, 13, 1(51), 70-81.

Duliniec, E. (2011). Koncepcje przedsiębiorstw wcześnie umiędzynarodowionych. Rozważania terminologiczne. Gospodarka Narodowa, 1-2, 63-80.

Ghemawat, P. (2001). Distance still matters: The hard reality of global expansion. Harvard Business Review, 79(8), 137-147.

Jarosiński, M. (2013). Procesy i modele internacjonalizacji polskich przedsiębiorstw. Warszawa: Oficyna Wydawnicza Szkoły Głównej Handlowej.

Johanson, J., Vahlne, J.E. (1977). The Uppsala Internationalization Process Model of Knowledge Development and Increasing Foreign Commitments. Journal of International Business Studies, $8(1), 23-32$.

Johanson, J., Vahlne, J.E. (1990). The mechanism of internationalization. International Marketing Review, 7(4), 11-24.

Johanson, J., Wiedersheim-Paul, F. (1975). The Internationalization of the Firm: Four Swedish Cases. Journal of Management Studies, 12(3), 305-322.

Kuivalainen, O., Sundqvist, S., Saarenko, S. (2012). Internationalization Patterns of Small and Mediumsized Enterprises. International Marketing Review, 21(6), 645-665.

Madsen, T.K., Servais, P. (1997). The Internationalization of Born Globals: an Evolutionary Process? International Business Review, 6(6), 561-583.

Nordstrom, K., Vahlne, J.E. (1994). Is the globe shrinking? Psychic distance and the establishment of Swedish sales subsidiaries during the last 100 years. W: M. Landeck (red.). International trade: Regional and global issues. New York: St Martin's Press, 41-56.

O'Grady, S., Lane, H.W. (1996). The psychic distance paradox. Journal of International Business Studies, 27(2), 309-333.

Ojala, A., Kontinen, T. (2010). Distance Factors in the Foreign Market Entry of Software SMEs. W: Software Business. Springer, 49-62.

Vahlne, J.E., Ivarsson, I. (2014). The globalization of Swedish MNEs: Empirical evidence and theoretical explanations. Journal of International Business Studies, 45(3), 227-247.

Wach, K. (2014). Theoretical Framework of the Firm-Level Internationalisation in Business Studies. W: A. Durendez, K. Wach (red.). Patterns of Business Internationalisation in Visegrad Countries - In Search for Regional Specifics. Cartagena: Universidad Politécnica de Cartagena, 13-32.

Nelly Daszkiewicz, dr hab., prof. nadzwyczajny Politechniki Gdańskiej, Wydział Zarządzania i Ekonomii, Katedra Nauk Ekonomicznych. Autorka i współautorka kilku książek i kilkudziesięciu artykułów naukowych, przede wszystkim z obszaru internacjonalizacji przedsiębiorstw. Kierunki prowadzonych badań obejmują również aspekty funkcjonowania małych i średnich przedsiębiorstw. 
Nelly Daszkiewicz, Associate Professor of Gdansk University of Technology, Faculty of Management and Economics. Author and co-author of several books and dozens of scientific articles, mainly in the area of internationalization of enterprises. Directions of research also include the areas of small and medium enterprices.

\section{Adres/address}

Politechnika Gdańska

Wydział Zarządzania i Ekonomii

Katedra Nauk Ekonomicznych

ul. Narutowicza 11/12, 80-952 Gdańsk, Polska

e-mail: Nelly.Daszkiewicz@zie.pg.gda.pl 